\begin{tabular}{|c|c|}
\hline & $\begin{array}{c}\text { Mavrilimumab total } \\
(\mathrm{n}=442)\end{array}$ \\
\hline \multicolumn{2}{|l|}{ Demographics } \\
\hline Age, years, median (min-max) & $52(19-79)$ \\
\hline Sex, \% female & 85.1 \\
\hline \multicolumn{2}{|l|}{ BL disease characteristics } \\
\hline Years since RA diagnosis, mean (SD) & $7.91(6.85)$ \\
\hline MTX dose, mg/week, mean (SD) & $15.00(6.84)$ \\
\hline DAS28-CRP, mean (SE) & $5.77(0.04)$ \\
\hline \multicolumn{2}{|l|}{ Concomitant pulmonary disease, $\mathrm{n}(\%)^{\mathrm{b}}$} \\
\hline $\begin{array}{l}\text { Asthma } \\
\text { COPD } \\
\text { Other }\end{array}$ & $\begin{array}{r}17(3.8) \\
8(1.8) \\
21(4.8)\end{array}$ \\
\hline Ever smoked, $\mathrm{n}(\%)$ & $134(30.3)$ \\
\hline Current smokers, $n(\%)$ & $76(17.2)$ \\
\hline RF and ACPA positive, $n(\%)$ & $359(81.2)$ \\
\hline \multicolumn{2}{|l|}{ BL pulmonary function } \\
\hline \% predicted $\mathrm{FEV}_{1}$, mean $(\mathrm{SD})$ & $93.9(14.7)$ \\
\hline \% predicted FVC, mean (SD) & $94.0(14.6)$ \\
\hline$\%$ predicted DLCO, mean $(\mathrm{SD})[\mathrm{n}]$ & $72.4(9.3)[48]$ \\
\hline Borg dyspnoea score, mean (SE) & $0.4(0.0)$ \\
\hline \multicolumn{2}{|l|}{ Efficacy results } \\
\hline \multicolumn{2}{|l|}{ Borg dyspnoea score, mean (SE) [N] } \\
\hline Week $12^{\text {cd }}$ & NA \\
\hline Week 74 & $0.3(0.0)[279]$ \\
\hline Week 134 & $0.3(0.0)[58]$ \\
\hline \multicolumn{2}{|c|}{$>20 \%$ reduction from $\mathrm{BL}$ to $80 \%$ predicted $\mathrm{FEV}_{1}, \mathrm{n} / \mathrm{N}(\%)$} \\
\hline Week $12^{\text {cd }}$ & $2 / 298(0.7)$ \\
\hline Week 74 & $8 / 231(3.5)$ \\
\hline Week 104 & $11 / 178(6.2)$ \\
\hline Week 130 & $1 / 29(3.4)$ \\
\hline \multicolumn{2}{|c|}{$>20 \%$ reduction from $\mathrm{BL}$ to $80 \%$ predicted $\mathrm{FVC}, \mathrm{n} / \mathrm{N}(\%)$} \\
\hline Week $12^{\text {cd }}$ & $2 / 298(0.7)$ \\
\hline Week 74 & $7 / 239(2.9)$ \\
\hline Week 104 & $3 / 177(3.4)$ \\
\hline Week 130 & $0 / 32(0.0)$ \\
\hline
\end{tabular}

Mavrilimumab total=all atientswho received mavrilimumab in either of the two randomised studies or three studies. 'Between weeks 12 and $24,3(3.8 \%), 8(9.4 \%), 12(14.8 \%)$ and $37(45.7 \%)$ pts receiving
mavrilimumab $150 \mathrm{mg}, 100 \mathrm{mg}, 30 \mathrm{mg}$ eow, and placebo, respectively, transferred from NCT017065 the $O L E$ study because of lack of efficacy. ${ }^{\circ}$ Between Weeks 12 and $24,22.9 \%$ ) and $0.00 \%$ p pts receiving mavrilimumab $10 \mathrm{mg}$ and golimumab $50 \mathrm{mg}$, respectively, transferred from NCT017 15896 to the OLE study because of lack or eficacy DAS28-CRP, disease activity score 28 ady; BL, baseline; COPD, chronic obstructive pulmonary disease; nonoxide; eow, every other week; FEV1, forced expiratory volume in 1 second; FVC, forced vital capacity

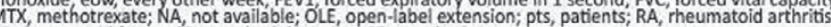
$\mathrm{RE}$, rheumatoid factor; $S \mathrm{D}$, standard deviation; $S E$, standard error

Scotland, charity number SC004401 Grant/research support: Research award to University of Glasgow], Consultant for: Medlmmune, M. Albulescu Shareholder of: Medlmmune, Employee of: Medlmmune, M. Weinblatt Grant/research support from: BMS, UCB, Crescendo Bioscience. Amgen, dxterity, Consultant for: MedImmune, Astra Zeneca, Amgen, Abbvie, BMS, Crescendo bioscience, Lilly, Pfizer, UCB, Roche, novartis

DOI: 10.1136/annrheumdis-2017-eular.3131

\section{FRI0217 IMPACT OF RITUXIMAB IN COMBINATION WITH LEFLUNOMIDE AND RITUXIMAB RETREATMENT WITH TWO DIFFERENT DOSAGES ON PATIENT-REPORTED OUTCOMES: RESULTS FROM A MULTICENTER RANDOMIZED PLACEBO CONTROLLED INVESTIGATOR INITIATED CLINICAL TRIAL IN ACTIVE RHEUMATOID ARTHRITIS (AMARA-STUDY)}

M. Köhm ${ }^{1,2}$, T. Rossmanith ${ }^{2}$, S. Dauth ${ }^{2}$, R. Alten ${ }^{3}$, M. Aringer ${ }^{4}$, M. Backhaus ${ }^{5}$, G. Burmester ${ }^{6}$, E. Feist ${ }^{6}$, H. Kellner ${ }^{7}$, K. Krüger ${ }^{8}$, U. Müller-Ladner ${ }^{9}$,

A. Rubbert-Roth ${ }^{10}$, H.-P. Tony ${ }^{11}$, S. Wassenberg ${ }^{12}$, H. Burkhardt ${ }^{1,2}$,

F. Behrens ${ }^{1,2}$ on behalf of AMARA study group ${ }^{1}$ Rheumatology,

Goethe-University Frankfurt/Main, Frankurt/Main; ${ }^{2}$ Clinical Research, Fraunhofer IME-TMP, Frankfurt; ${ }^{3}$ Rheumatology, Schlosspark-Klinik, Berlin; ${ }^{4}$ Medizinische Klinik und Poliklinik III, Universitätsklinik, Dresden: ${ }^{5}$ Rheumatologie, Park-Klinik Weißensee; ${ }^{6}$ Rheumatologie, Charité Universitätsmedizin, Berlin;

${ }^{7}$ Rheumatologische Fachpraxis; ${ }^{8}$ Praxiszentrum St. Bonifatius, München;

${ }^{9}$ Abteilung Rheumatologie und klinische Immunologie, Kerckhoff-Klinik, Bad Nauheim; ${ }^{10}$ Rheumatologie, Universitätsklinik, Köln; ${ }^{11}$ Abteilung Rheumatologie/Immunologie, Universitätsklinik, Würzburg; ${ }^{12}$ Rheumazentrum, Ratingen, Germany

Background: Use of biologicals such as Rituximab (RTX) in Rheumatoid Arthritis (RA) is effective and often only licensed in combination with Methotrexate (MTX). In cases of contraindications to or intolerances of MTX other cDMARDs are frequently used without robust data from RCTs. In addition, different strategies of retreatment of RTX are available.

Objectives: To demonstrate efficacy on patient-reported outcomes (PROs) of RTX in combination with leflunomide (LEF) in a multicenter investigator-initiated placebo (PLA)-controlled RCT in Germany.

Methods: A total of 189 patients with active RA (DAS28>3.2 and at least 3 SJC and $3 \mathrm{TJC}$ ) despite stable LEF treatment were screened for a 52-weeks double-blind placebo controlled RCT. Patients were randomized to receive either two-times $1000 \mathrm{mg}$ RTX i.v followed by a retreatment at week 24 with two-times 1000 (RTX-RTXhigh) or 500mg (RTX-RTXlow) or two times PLA at baseline, followed by a retreatment of RTX of either two-times 1000 (PLA-RTXhigh) or $500 \mathrm{mg}$ (PLA-RTXlow) at week 24. Adult patients who had inadequate response to more than one antiTNF or failed more than three cDMARDs were excluded. PROs (HAQ, FACIT-F, SF36) were measured at each visit until week 52. Treatment effects on PROs were determined by differences from baseline to week 16, 24 and week52.

Results: Of 189 screened patients 148 were randomized (mean age 56 years; mean proportion of RF-and antiCCP-positivity $58.4 \%$ and $55.7 \%$ in the RTX-group; $74 \%$ female). DAS28 at baseline was 5.55 for RTX and 5.53 in the PLA-group. All baseline-characteristics were well balanced between treatment groups. An improvement in $\mathrm{HAQ}$ from baseline to week 16 was seen with a mean delta of -0.23 in the RTX-group (MCID) vs. -0.11 for PLA. In the RTX-group, retreatment until week 52 resulted in stable HAQ-values compared to week24 independent from its dosage. FACIT-F values increased in the RTX-group from baseline to weeks 16,24 and 52 by $11.87,12.3$ and 14.25 , respectively. All physical and mental domains of the SF36 showed a pronounced increase of levels at week 16 compared to baseline in the RTX-group (Figure 1). A total of 372 adverse events $(\mathrm{AE})$ were observed during the one-year studyperiod, only 14 classified as severe (10 in RTX and 4 in PLA). 43 serious adverse events were reported, 28 of them in the RTX-group during the placebo-controlled period.

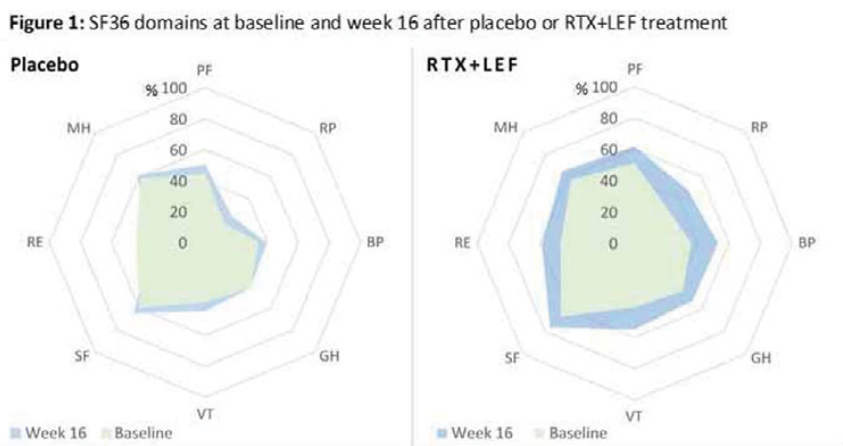

PF: physical functioning: RP: physical role limitations; BP: pain; GH: general heal th; VT: energy/vitality SF: social functioning, RE: emotional role limitations, $\mathrm{MH}$ : mental health

Conclusions: Efficacy of LEF plus RTX was demonstrated not only by measurements of disease activity (as presented previously) but also by measurements of PROs (HAQ, FACIT-F, SF36). This treatment regime showed equal effect sizes compared to the combinational therapy of MTX plus RTX. The treatment with LEF plus RTX illustrated an acceptable safety profile.

Disclosure of Interest: M. Köhm Grant/research support from: Pfizer, Janssen, Consultant for: Janssen, T. Rossmanith Grant/research support from: Janssen, Pfizer, Roche, S. Dauth: None declared, R. Alten Grant/research support from: Roche, M. Aringer Grant/research support from: Roche, M. Backhaus Grant/research support from: Roche, G. Burmester Grant/research support from: Roche, E. Feist Grant/research support from: Roche, H. Kellner Grant/research support from: Roche, K. Krüger Grant/research support from: Roche, U. MüllerLadner Grant/research support from: Roche, A. Rubbert-Roth Grant/research support from: Roche, H.-P. Tony Grant/research support from: Roche, S. Wassenberg Grant/research support from: Roche, H. Burkhardt Grant/research support from: Roche, Pfizer, Speakers bureau: Pfizer, BMS, F. Behrens Grant/research support from: Roche, Pfizer, Janssen, Speakers bureau: BMS, Janssen, Pfizer, AbbVie

DOI: 10.1136/annrheumdis-2017-eular.6238

\section{FRI0218 SHARED EPITOPE POSITIVITY IS RELATED TO EFFICACY OF ABATACEPT IN RHEUMATOID ARTHRITIS}

K. Oryoji, K. Yoshida, S.-I. Mizuki. Matsuyama Red Cross Hospital, JAPAN, Matsuyama-Shi, Japan

Background: Abatacept, a soluble fusion protein composed of the extracellular domain of CTLA-4 molecule and the Fc portion of human $\lg \mathrm{G} 1$, is approved therapy for RA by the mechanism of binding to CD80/86 (B7-1/B7-2) on antigen presenting cell (APC), and blocking the B7:CD28 interaction. Meanwhile, it is suggested that HLA-DRB1 shared epitope (SE) associates with the production of ACPA through MHC molecule-based antigen presentation. Moreover, the association between the efficacy of abatacept and the positivity for anti-cyclic citrullinated peptide antibody (ACPA) was reported. Thus, we speculated that there may be correlation between the efficacy of abatacept and patients' HLA-DRB1 SE positivity, so we investigated correlation between the clinical efficacy of abatacept in RA patients and their HLA-DRB1 genotype.

Objectives: To identify the relation between the efficacy of abatacept on patients with rheumatoid arthritis (RA) and their HLA-DRB1 phenotype including whether having shared epitope (SE).

Methods: HLA-DRB1 phenotype of 72 patients treated with abatacept was identified, and divided into 2 group, SE (HLA-DRB1 0101, 0401, 0404, 0405 
0408, 1001) positive and SE negative. To overcome potential bias, multivariate logistic regression analysis was done in this retrospective cohort.

Results: They were divided into 47 SE positive patients (65.3\%) and 25 SE negative patients $(34.7 \%)$. The retention rate of abatacept treatment at week 52 were $95.3 \% / 47.1 \%$ (SE positive/SE negative, $p<0.0001$, log-rank test), respectively. Adjusted hazard ratio for abatacept discontinuation due to lack of efficacy was 8.94 (95\% Cl: 2.95-34.1, $\mathrm{p}<0.0001$, Multivariable Cox proportional hazards regression model) in SE negative group compared to SE positive group. The EULAR good response rate at week 24 were $74.5 \% / 20.0 \%$ (SE positive/SE negative, $p<0.0001$, Fisher's exact test), respectively. Simplified Disease Activity Index (SDAI) remission rate at week 24 were $55.3 \% / 20.0 \%$ (SE positive/SE negative, $\mathrm{p}=0.004$, Fisher's exact test), respectively. Multivariate logistic regression revealed the odds ratio of EULAR good response and SDAI remission achievement in SE positive patients was 23.2 and $6.73(95 \% \mathrm{Cl}$ : $5.10-152.0, p<0.0001$ and $1.70-32.3, p=0.006)$, respectively.

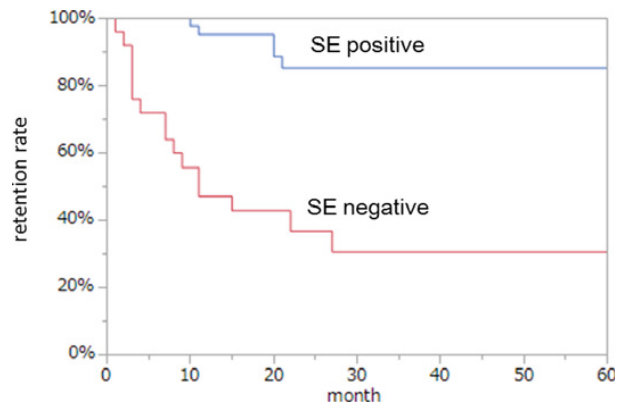

Conclusions: Abatacept is strictly effective to SE positive RA patients.

Disclosure of Interest: K. Oryoji Grant/research support from: Ono, Speakers bureau: Abbvie, Chugai, Astellas, Mitsubishi-Tanabe, Pfizer, Janssen, Eisai, UCB and Ono, K. Yoshida: None declared, S.-I. Mizuki Speakers bureau: Abbvie, Astellas, Mitsubishi-Tanabe, Pfizer, Janssen, Eisai, UCB and Ono

DOI: 10.1136/annrheumdis-2017-eular.5586

\section{FRI0219 ASSOCIATION BETWEEN CONVERSION TO ACPA/RF SERONEGATIVE STATUS AND CLINICAL OUTCOMES FOLLOWING TREATMENT WITH ABATACEPT IN COMBINATION WITH METHOTREXATE COMPARED WITH METHOTREXATE ALONE IN PATIENTS WITH EARLY RHEUMATOID ARTHRITIS AND POOR PROGNOSTIC INDICATORS}

D. Jansen ${ }^{1}$, P. Emery ${ }^{2}$, J. Smolen ${ }^{3}$, R. Westhovens ${ }^{4}$, M. Le Bars ${ }^{5}$,

S. Connolly ${ }^{6}$, J. Ye ${ }^{6}$, R. Toes ${ }^{1}$, T. Huizinga ${ }^{1} .{ }^{1}$ Leiden University Medical Center, Leiden, Netherlands; ${ }^{2}$ University of Leeds and Leeds Musculoskeletal Biomedical Research Unit, Leeds, United Kingdom; ${ }^{3}$ Medical University of Vienna, Vienna, Austria; ${ }^{4}$ UZ Gasthuisberg, Leuven, Belgium; ${ }^{5}$ Bristol-Myers Squibb, Rueil-Malmaison, France; ${ }^{6}$ Bristol-Myers Squibb, Princeton, United States

Background: RA is characterized by the production of autoantibodies, including anti-citrullinated protein antibodies (ACPA) and RF, which are associated with poor prognosis in RA..$^{1-3}$ More data on the clinical significance of ACPA/RF seroconversion in response to treatment are needed. Evidence suggests a role for T cells in ACPA production. 2,3

Objectives: This post hoc analysis investigated the effect of the T-cell costimulation modulator abatacept (ABA) in combination with MTX vs MTX alone on conversion of ACPA positive (+) and RF+ patients (pts) to seronegative status, and the relationship between conversion to seronegative status and clinical response. Methods: Data from a double-blind, randomized, Phase III study (AGREE; NCT00122382) conducted in MTX-naïve pts with early RA ( $\leq 2$ years) and poor prognostic factors (ACPA+ and/or RF+ with evidence of erosions) were included. ${ }^{4}$ Pts were randomized to ABA ( $\sim 10 \mathrm{mg} / \mathrm{kg}$ IV according to weight)+MTX or placebo+MTX (MTX alone) in a 12-month (M) double-blind phase followed by 12M of open-label ABA+MTX. Autoantibody titres were assessed at baseline and $6 \mathrm{M}$ and $12 \mathrm{M}$ of the double-blind phase by ELISA. Pts with titres below the threshold for positivity (ACPA $5 \mathrm{AU} / \mathrm{mL} ; \mathrm{RF}$ [lgM] $15 \mathrm{IU} / \mathrm{mL}$ ) at M6 or M12 were considered to have converted to seronegative status. The relationship between conversion to ACPA seronegative status and clinical response at M6 and M12 was determined. All analyses were descriptive and based on pts with available DAS28 (CRP) and CDAl data at baseline and $\mathrm{M} 6$ and $\mathrm{M} 12$.

Results: A total of 435 and $461 \mathrm{pts}$, respectively, were ACPA+ or RF+ at baseline and had known serostatus at M6 and M12. At 6M, 6.6\% (15/227) and $17.0 \%$ (39/230) of ABA+MTX pts were ACPA and RF negative, respectively, vs $2.9 \%$ (6/208) and 9.5\% (22/231) of MTX pts. At 12M, 7.1\% (15/212) and 18.5\% (41/222) of ABA + MTX pts were ACPA and RF negative, respectively, vs $4.5 \%(9 / 198)$ and $14.6 \%(32 / 219)$ of MTX pts. A higher proportion of pts receiving ABA + MTX who converted to ACPA seronegative status achieved remission (DAS28 $[C R P]<2.6$ or $C D A I \leq 2.8)$ compared with ABA + MTX-treated pts who remained ACPA+ or with pts treated with MTX alone regardless of whether they converted to seronegative status or not (Figure). Pts receiving ABA + MTX who converted to ACPA seronegative status also had a numerically higher cumulative probability of achieving sustained remission (DAS28 [CRP] <2.6) and lower radiographic progression than pts receiving MTX who converted to seronegative status or pts in either treatment group who remained ACPA+ (data not shown).

Figure, Proportion of Patients Achieving Remission, According to DAS28 (CRP)-Defined or CDAI Criteria, by ACPA Seronegative/Seropositive Status
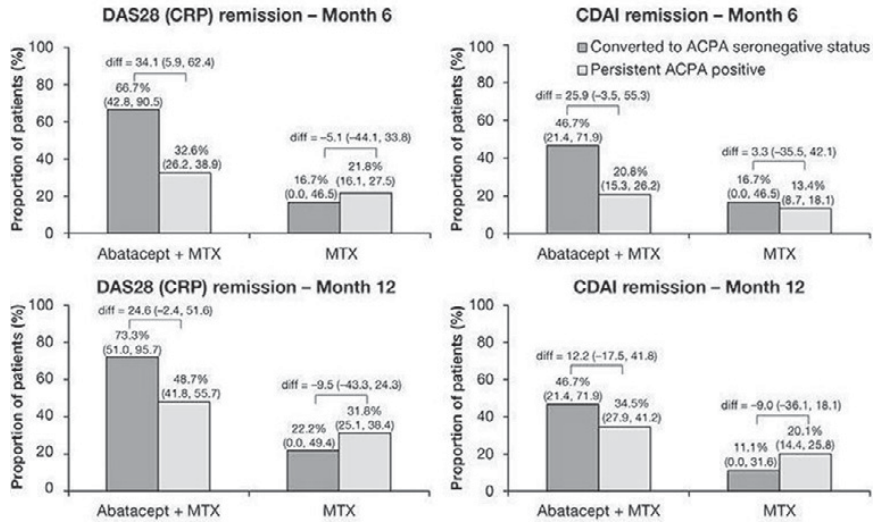

Baseline to Month 6 and baseline to Month 12 were carried out as separate analyses.

Conclusions: Compared with MTX alone, treatment with abatacept + MTX was more likely to result in conversion to ACPA/RF seronegative status in pts with early erosive RA. Conversion to ACPA seronegative status was associated with better clinical and radiographic outcomes.

References:

[1] Scott DL, et al. Lancet 2010;376:1094-108.

[2] Hecht C, et al. Ann Rheum Dis 2015;74:2151-6.

[3] Aletaha D, et al. Arthritis Res Ther 2015;17:229.

[4] Rombouts Y, et al. Ann Rheum Dis 2016;75:578-85.

Disclosure of Interest: D. Jansen: None declared, P. Emery Grant/research support from: AbbVie, Merck, Pfizer, Roche, Consultant for: AbbVie, BristolMyers Squibb, Merck, Pfizer, Roche, Lilly, Novartis, Samsung Bioepis, J. Smolen Grant/research support from: AbbVie, Janssen, Lilly, MSD, Pfizer, Roche, Consultant for: AbbVie, Amgen, AstraZeneca, Astro, Bristol-Myers Squibb, Celgene, Celltrion, Chugai, Gilead, GSK, ILTOO, Janssen, Lilly, Medlmmune, MSD, NovartisSandoz, Pfizer, Roche, Samsung, Sanofi, UCB, R. Westhovens Grant/research support from: Roche, Consultant for: Janssen, Celltrion, Galapagos, Speakers bureau: Bristol-Myers Squibb, M. Le Bars Shareholder of: Bristol-Myers Squibb, Employee of: Bristol-Myers Squibb, S. Connolly Shareholder of: Bristol-Myers Squibb, Employee of: Bristol-Myers Squibb, J. Ye Shareholder of: Bristol-Myers Squibb, Employee of: Bristol-Myers Squibb, R. Toes: None declared, T. Huizinga Grant/research support from: EU \& Dutch Arthritis Foundation, Consultant for: Abbott Laboratories, Biotest AG, Bristol-Myers Squibb, Crescendo Bioscience, Inc, Novartis Pharmaceuticals Corporation, Pfizer Inc, Roche, sanofi-aventis, Schering-Plough, UCB, Inc., Eli Lilly, Speakers bureau: Abbott Laboratories, Biotest AG, Bristol-Myers Squibb, Novartis Pharmaceuticals Corporation, Pfizer Inc, Roche, sanofi-aventis, Schering-Plough DOI: 10.1136/annrheumdis-2017-eular.1716

\section{FRI0220 ALLOGENEIC MESENCHYMAL PRECURSOR CELLS (MPCS): A NOVEL APPROACH TO TREATING BIOLOGIC REFRACTORY RHEUMATOID ARTHRITIS}

S. Kafaja ${ }^{1}$, K.R. Segal ${ }^{2}$, D. Skerrett ${ }^{3}$, S. Itescu ${ }^{4}$, D.E. Furst ${ }^{5} .{ }^{1}$ Division of Rheumatology, David Geffen School of Rheumatology, University of California Los Angeles, Los Angeles; ${ }^{2}$ Mesoblast, Inc; ${ }^{3}$ Mesoblast, Inc, New York, United States; ${ }^{4}$ Mesoblast, Inc, Melbourne, Australia; ${ }^{5}$ Arthritis Associates of Southern California, Los Angeles, United States

Background: Allogeneic STRO-3 immunoselected mesenchymal precursor cells (MPCs) derived from bone marrow of healthy donors are a potent, homogeneous cell population which can be activated by pro-inflammatory cytokines to release factors which polarize pro-inflammatory monocytes and $\mathrm{T}$ cells to an antiinflammatory state. This is the first in human trial to assess MPC therapy in biologic refractory RA, a disease driven by monocyte and $T$ cell activation.

Objectives: To assess the safety and tolerability and to explore the clinical efficacy of MPC therapy in RA.

Methods: MSB-RA001 is a phase $1 \mathrm{~B} / 2 \mathrm{~A}$ randomized, double-blind, placebocontrolled, sequential, dose-escalation trial to assess the safety and explore efficacy of a single intravenous (IV) infusion of MPCs in patients with active RA who had failed to respond to at least one biologic. Efficacy endpoints included ACR $20,50,70$, ACR core components, $\mathrm{HAQ}$ and DAS28. Patients were randomized to receive one IV infusion of MPC 1 million cells/kg $(n=16), 2$ million cells/kg $(n=16)$, or placebo $(n=16)$ in 2 sequential dose cohorts. The primary study period was 12 weeks.

Results: Patients in all 3 treatment groups ( $\mathrm{N}=16$ per group) were comparable in mean age (55 y), gender ( $73 \%$ women), duration of RA (14 years) and 